\title{
Criminology in the Face of Flows: Reflections on Contemporary Policing and Security Introduction to the special issue
}

\begin{abstract}
:
Much has been written about the governance of crime - indeed this is the thread that has unified criminology. Yet, mere property crimes and attacks against individuals - traditionally at the core of the discipline - are plummeting in many societies. Meanwhile, harms and harms management emerge outside the narrowness of criminal justice definitions. Despite this, very little criminological attention has been paid to the fact that the security of flows increasingly embodies concerns that are at the heart of contemporary policing practices. This introduction to this special issue takes stock of these changes, and argues that to stay current and relevant, criminology must pay closer attention to these changing landscapes of harms and policing.
\end{abstract}


Our institutions of security governance have been profoundly shaped by $18^{\text {th }}$ and $19^{\text {th }}$ Century European political developments that gave rise to the institutions of criminal justice (Brodeur 2010). Central to these developments has been the emergence of policing arrangements (see for example, Radzinowicz 1948 and Beattie 2002; 2012) that governments have developed to "shape the flow of events" (Parker et al. 2004). For the most part, those arrangements relate to the interpersonal "hitting and taking" harms that criminal codes, and popular sensibilities, categorize as "crime".

One institutional development that has fundamentally shaped contemporary policing, particularly within the anglo-sphere, was the emergence of the Marine Police Force in 1798, a private policing organisation. Established by the magistrates and security governance reformers Patrick Colquhoun and John Harriot, it was created to maintain security within the London's dockyards. This preventatively focused security organisation foreshadowed, and provided inspiration for the establishment of the publically funded London Metropolitan Police three decades later. Both these developments arose in response to concerns, particularly by business interests, about the state of the "institutions of privacy" (Stinchcombe 1963). At the centre of these concerns, both in the dockyards and in the City of London more broadly, was the secure flows of people and goods.

Much has been written about the governance of crime - indeed this is the thread that has unified criminology. Yet, mere property crimes and attacks against individuals - traditionally at the core of the discipline - are plummeting in many societies. Meanwhile, harms and harms management emerge outside the narrowness of criminal justice definitions while "securing circulation" of flows is still presented as the dominant liberal problematic of security (Boy 2015; Dillon 2005; Langley 2013; Lobo-Guerrero 2008). Despite this, very little criminological attention has been paid to the fact that the security of flows increasingly embodies concerns that are at the heart of contemporary policing practices (but see McCulloch and Pickering 2012). Indeed, the focus within contemporary security governance of fortifying urban spaces, through gating communities and other spaces and securing the conduits that connect them (Shearing 1999), only became a sustained focus of criminological attention during the last two decades of the $20^{\text {th }}$ Century (for a review see Bayley and Shearing 1996). This logic of fortification has now spread beyond a concern for crime and into the management of mobile populations. The "fortified enclaves" (Caldeira 1996; Brown 2010) that shape so much of contemporary life, at a variety of scales, and particularly the governance of flows that maintain these spaces - from gated communities to "fortified continents" (Aas 2007) and migrant imprisonment (Bosworth 2014) - still receive remarkably little attention within criminology. This gap has created a 
failure to locate the security of the flows that define, and are maintained within, our elaborately fortified worlds.

Becoming a central feature of security governance at the centre of the criminological stage, such logics of fortification are also intersecting with a concern for filtering flows. From barriers to smart borders, mechanisms to govern global flows are "sociotechnical devices" (Amicelle et al. 2015) that aim to both intercept and facilitate the flows of people and things, while gathering information on those flows (Pallister-Wilkins 2016). There is no better symbol than the airport to make clear the twin and apparently contradictory claims of our time: to maximise but to regulate flows (Lyon 2007). The policing of crime has also begun to change significantly as the harm landscapes associated with terrorism - and more recently digital and environmental harms - have emerged as a defining feature of the $21^{\text {st }}$ Century. This has been evident notwithstanding scholarship on flows associated with the work of Manuel Castells and his identification of the crucial role played by "flows of capital, flows of information, flows of technologies, flows of organizational interaction, flows of images, sounds, and symbols" (2010 [2000], p. 442) within our increasingly digital societies, in which cyberspaces and artificial intelligences have become such ubiquitous features of the global flows that characterise our "world[s] in motion" (Aas 2007).

Taking stock of those changes, some policing and security research in the past two decades has started examining new types of harms in the form of flows and the regulation efforts that accompany these harms. Accordingly, criminological scholarship has developed its analysis of how flows of people, information and things have changed policing and how conversely, policing intervenes and shapes those flows. The initial path breaking forays into these novel conditions include interest for merging forms of transnational policing (Bowling and Sheptycki 2012), international drug trafficking control (Nadelmann 1993), the regulation of financial flows and "dirty money" (Levi and Reuter 2006) and the role of information technologies in police work (Ericson and Haggerty 1997). While continuing to receive interest, these contemporary trends in policing have been joined by investigations aiming at making sense of new complex phenomena related to the policing of/through flows. Recent advances have been made in areas as diverse as the policing of migration (Aliverti 2015), border security (Côté-Boucher 2016; Loftus 2015), financial security (Amicelle and Jacobsen 2016; De Goede 2012), criminal networks (Morselli 2010), surveillance of transportation hubs, ports and supply chains (Brewer 2014), cross-border environmental crime, cybercrime and online radicalization, as well as online surveillance, by private interests and governments. We argue that we are now dealing with a transition where we are less concerned with 
harms management narrowly conceived and more with the relation between harms management and the management of flows. This introduction sets the stage to ask: what kind of knowledge do we need to build to tackle this relation in order to set the course for a new vision of criminology for the $21^{\text {st }}$ century?

In this perspective, we first refer to a conception of security that is both de-essentialised and disembodied from a classic and exclusive state-organised social control. Security remains an "essentially contested concept" (Buzan 1991) used to capture very different set of activities and issues inside the disciplines of anthropology, criminology, history, international relations, political science and sociology (Bigo 2014). A nominative view is probably the most common within these major social sciences disciplines, where security is treated as a public good, value or right, it is given substance in the form of a human need. Here, security is thought as a set of measures and procedures that come to be seen as a normal part of our lives or are thought to be necessary to attain this normalcy. This "normalization" of security (as a necessary part of our lives, a sentiment of being secure) has the advantage of taking security away from statist reflexes that equate security with exception and the survival of the nation-state. It opens up possibilities to reclaim the idea of security as emancipation from physical and human constraints for people (Booth 1991). Therefore, security here coincides with the possibility to improve one's sense of security. Yet, if security is, first and foremost, a sentiment (Delumeau 1989) or an instrumental value (Booth 2007), our grasp of it becomes more elusive and more difficult to measure. When is there "enough" security for "whom" and from "what"? Such questions open up the black box of security and leave aside an illusory search for its core meaning to privilege inquiries into "what people do in its name" and "the practices of governance" (Valverde 2010, p. 5) that stem from this black box. Indeed, security is "not only an analytical category, but also a category of practice, a way of framing and responding to social problems" (Zedner 2003, p. 158). In other words, "when security policy and institutions enact a situation, they change the framing and legitimate repertoires of action by reiterating the existence of insecurities and by seeking to govern political and social relations as potentially inimical, dangerous or risky. In that sense, security practice always securitises; it necessarily inscribes insecurities in the world" (Huysmans 2014, p. 4). While security as a practice with a political content is about securing against insecurities, it becomes more interesting to analyse what the securing process does rather than what security means (Balzacq et al. 2010). Empirically, speaking of the relation between security, policing, harms and flows thus also requires investigating anew the contours of contemporary harms, who names, frames and manages them (or fails to do so) and is accountable for these harms. The 
emerging criminology of these and similar developments is leading to significant advances in understandings of the changing landscapes of harms and policing.

\section{Presentation of the special issue}

The workshop, held at the University of Montreal in November 2015, from which this Special Issue arises, was intended as an event that would enable criminological scholars to come together to recognise this elephant and explore its contours. The distinction that this workshop has incorporated in its title - namely policing of, and through, flows - emerged as a central thread and constitutes an integrating theme of the papers that make up this volume. The focus is therefore on how the growing centrality of flows affects both the nature of these contemporary risks and the policing organizations in charge of managing them.

Together these papers make a significant contribution to the security governance of flows focus that inspired this workshop. These include licit and illicit flows of money, migration, and animal parts considered in these essays, as well as flows of many other commodities, from pharmaceuticals to minerals or malicious software. The emerging criminology of these and similar developments portrayed in these papers is leading to significant advances in understandings of the changing harm landscapes and the practices that have developed to manage them.

In developing this of and through flows theme, Molnar and Whelan, in their essay, have looked to Michel Foucault and his ideas on "circulation" for inspiration. With this concept in mind they have turned their attention to what might be learned about the policing of and through flows from the arrangements, and associated practices, that were put in place to secure the G20 summit held in Brisbane, Australia in September 2014. In their essay they explore how "security and policing operations during major events involve various measures that, when taken together, introduce greater flexibility and mobility for police to regulate public disorder (as a circulation of flows) as well as better manage their own internal flows of information and people, both hierarchically and vertically, within command and control structures." Through their analysis they demonstrate how the "policing of flows is ... predicated on complex underlying systems of policing through flows." They conclude by arguing that "Policing is ... heavily contingent on managing both the policing of flows ... and the policing through flows."

Hubschle, with a very different empirical focus, moves from the policing of the flows surrounding a single location, namely a mega event, to the complex task of policing that seeks to disrupt the global flows that characterise illicit economies. In doing so, she takes the reader away 
from the highly controlled spaces, like the Brisbane G20, to the complex terrains and pathways through which rhino horn is taken from the body of these endangered animals to the markets of East Asia, where, for a variety of reasons, their horns are regarded as having potent medicinal and status value. Hubschle traces how policing agencies have been, with disastrous results for wildlife conservation, spectacularly unsuccessful in effectively disrupting flows of rhino horn.

Using the waterways metaphor of "locks" and "dams", Hufnagel's essay explores the governance of border security within the context of the European Union. The effective governance of external borders that have played such a vital role in enabling the opening up of internal borders has recently been fundamentally challenged by the massive flows of undocumented migrants fleeing the conflicts and poverty that today characterise many Northern African nations. Hufnagel compares this analysis of European border controls with an analysis of the governance of flows within Greater China. In developing her analysis, Hufnagel points to the importance of trust and legitimacy in shaping the organisational flows that enable the policing of flows. Trust and legitimacy, she argues, shape both the formal and informal forms of cooperation within and between organisations with regard, in particular, to the sharing of intelligence (a through flow), upon which the policing of flows depends. Hufnagel concludes that legitimacy shapes trust and, hence, enhances levels of cooperation between police agencies.

Two papers within the special issue that focus attention very directly on flows of information (intelligence) within security governance organisations are Sanders and Jeandesboz. Both authors focus their fine-grained attention on the way in which information flows within and between security and policing agencies. For Sanders, a crucial feature of these intra and inter organizational flows is "the way policing through flows of data has changed the symbolic nature of policing". Sanders develops this line of thought in her conclusion, where she recognizes the "way in which the technological frames of crime analysis run counter to traditional action-oriented practices of policing." In a complementary essay Jeandesboz takes the reader into the very heart of border security practices within the European Union by exploring the central role given to technological developments in information processing and information exchange. Attention is drawn particularly to the "centres of calculation" through which these policing flows are formed, transformed and directed.

In another essay focusing on organizational flows, the transnational policing scholar Shepticky takes the reader inside the "machine" to explore "information flows in the police organisation". In doing so he makes good use of Donald Rumsfeld's now classic distinction between "known knowns", "known unknowns" and "unknown unknowns" to provide a trenchant analysis of 
the dilemmas and challenges facing $21^{\text {st }}$ Century police organisations. Ultimately in facing these challenges, Shepticky concludes, police organisations have little choice but to base their strategies on the deep learning, centred in discretion, that have always enabled and defined "good policing".

Iafolla, in her essay takes us to what today, and certainly since $9 / 11$ has been the heartland of the (in)security of flows - namely "the life of flows of money and flows of information" that lie at the core of financial harms, such as money laundering and terrorist financing. As with other contributors to this volume Iafolla notes how the "policing of flows is inextricably linked with policing that takes place through flows". A major focus of Iafolla's analysis is what might be thought of as the "half life" - namely the staying power - of the "life of flows of information" developed to enable the governance of flows. Iafolla's essay focuses on the elaborate networks of enrolments that O’Malley (1996) and Garland (1996) have referred to as "responsibilization" that are used to identify and monitor risky flows of capital (Amicelle 2011).

Finally, Bigo takes a step back and proposes an in-depth reflection on the current state of scholarship about flows in the social sciences. He unravels the premise of contemporary security where flows are equated with chaos. The policing of flows responds to the international doxa where flows are seen as dangerous and in need of ordering, and where the figure of the state continues to "structure our relation to flows". Yet, building on Bauman's "liquid modernity", Bigo shows that flows responds to logics of distinction and social differentiation that go beyond the state: "Selfmonitoring and permanent monitoring coexist with profiling, therefore forging bonds and resistances differentiating the chains of commands and forms of allegiance that territory no longer follow". Alternatively, if, as Bigo suggests, we accept to view flows as "the logic of the social", we may be able to resist their (in)securisation.

\section{Why policing of/through flows in criminology?}

Thinking of security in terms of flows, as the papers in this volume do, has scholarly precedents outside of criminology's established boundaries. For instance, Michel Foucault (2009), in "Sécurité, territoire et population", tackled the issue of flows and their management in his explorations of disease management strategies within $17^{\text {th }}, 18^{\text {th }}$ and $19^{\text {th }}$ century European cities. What Foucault provided was an account of three political models of spatial control of flows of people and other mobile elements (carts, miasmas and so on) in relation to the management of leprosy, plague and smallpox. On the one hand, the first two models were based on a logic of enclosure with walls and related practices of territorial demarcation. While the management of leprosy relied on the extra muros exclusion of a certain segment of the population, the management of 
plague made quarantine compulsory with the quadrillage of city space to implement a strict regulation of movements intra muros. Both diseases thus refer to a problem of delimitation, whether the issue is about fixing an inside and an outside to block and exclude undesirable flows or it is about structuring territory to put and contain those flows in specific spaces. On the other hand, the management of smallpox through vaccination illustrated a third mode of spatial control with the "emergence of a completely different problem that is no longer that of fixing and demarcating the territory, but of allowing circulations to take place, of controlling them, sifting the good and the bad, ensuring that things are always in movement, constantly moving around, continually going from one place to another, but in such a way that the inherent dangers of this circulation are cancelled out" (Foucault 2009, p. 65). In other words, the main problem becomes first and foremost the mobility as such rather than the delimitation of space to the extent that the issue is about monitoring an entire mobile population all over the territory.

In light of the special issue, the value of Michel Foucault's work is twofold. First, this concern with the spread of disease through flows of "an indefinite series of mobile elements" (Foucault 2009, p. 20) is at least as important today as it was in the $19^{\text {th }}$ century - consider the recent outbreaks of Ebola and Zika. Secondly, and most importantly, Foucault also provides in this way three ideal-types of flows management (e.g. through exclusion; containment; traceability) to interrogate current policing configurations - whether they might predominantly relate to either one model or a specific articulation of various models or even the emergence of new modes of control.

For instance, today the traceability and "securitization" (Schuilenburg 2015) of flows is presented as central to the governance of security of population and the spaces they inhabit (Gros 2012). Indeed, the set of traceability techniques is designed and promoted to allow at any time the differentiation and relocation of flows without infringing upon the general principal of their circulation (Torny 1998). According to M-A. Hermitte (2003, p. 3), "surveillance, ancient reality, only becomes modern traceability when it is performed within an organized system, whose extension suggests that it is a genuine societal project, pursued by private powers as much as public powers". These developments, as the papers in this issue make clear, both draw upon, and extend, the pluralisation of security governance -- the securing of flows is fundamentally "nodal" (Shearing and Wood 2003) with heterogeneous networks that could be not only transnational but also hybrids between public and private actors (Bauman et al. 2014). As the classical categorization between public and private security actors becomes more and more obsolete, a growing symbiotic relationship between the State and major businesses interests has been observed (O'Reilly and Ellison 2006; 
O’Reilly 2010), which indicates an increasing ability of private actors to affect public policing dynamics and strategies.

As a result, a significant aspect of this policing of flows is the multiplication of the governance practices that trace, filter, scan and survey flows. How these secure an ordered circulation - this constitutive aim of liberal regimes - also conveys questions about how we globally reformulate inclusion and exclusion, as well as "social and political hierarchies, practices of rule and identities" (Kotef 2015, p. 3).

Therefore, thinking in terms of flows is conceptually promising, we argue, yet not new if one considers how this term is generalized when it comes to the study of security, but also when we account for the wide array of flows that is currently managed in different social spaces or sites of security. But what are flows, and how might this concept be useful in epistemological terms? What are the constitutive properties of flows that require a new conceptual model? How does this language of flows enable criminologists to explore new empirical terrains that were formerly ignored by traditional criminology?

In developing a criminology that pays attention to flows scholars need, through their research, to consider what is flowing, through what spaces, the strategies and practices that have been, and are being, developed to manage these flows and who engages in them. These are empirical questions that are likely to be answered differently in different contexts. This means highlighting the dynamic and adaptive nature of flows, such as being able to always find a path of least resistance (like water) to reach their goals, by contrast with a more static understanding of harms as located (or embedded) in physical spaces whose structural features represent powerful constraints. For instance, new technologies of communication and the Internet, mostly via social platforms (such as YouTube, Twitter or Facebook) have now massively expanded the capacity of hate speeches to harm people in a way that is not just located in specific physical spaces, such as right-wing extremist demonstrations online. It is these questions that the papers included in this volume, through empirical explorations, have sought to address.

Thinking in terms of flows calls for the identification and discussion of the spaces / sites that permit or impede certain kinds of mobilities - urban, cross-border, financial, digital and so on. The papers in this volume explore the way in which people, information, and goods, within very different domains, circulate between nodes or hubs where they are managed, shaped, directed and regulated. Through these processes of circulation, flows move from one space to another where they are 
shaped by processes, decisions and technologies. Those directing flows may also choose alternative pathways to avoid some shaping processes in favour of others (cf Braithwaite and Drahos's (2000), "forum shopping").

Focusing attention on flows also necessitates a recalibration of established understandings of regulatory actors to include a wide range of "actants" (see for example, Latour 2005). What actors (and actants) are involved in managing flows? What mentalities, technologies and practices do they employ? What outcomes are they seeking to realise? What vested interests are at stake? What resources are mobilized? In short how and by whom are different sets of flows policed within different contexts? For example, how is the idea of flows impacting when we consider security actors whose core business is to provide security (law enforcement actors, private policing) versus those whose business is not to provide security/policing services per se (bankers, truckers, internet companies)? One should identify them, assessing and studying their mentalities, the technologies they are mobilizing, as much as their knowledge, resources and capacities.

The normative frameworks that are being utilized to shape and assess the management of flows should also become a new focus of enquiry. We can investigate how they differ from established frameworks, but also what are the normative questions that are being raised, and how these new interrogations are being resolved by the policing of and through flows. The identification of the decision makers and the ways in which they articulate their different needs and interests is also a key topic of investigation, especially in light of the growing role of automated technologies in contemporary policing. Indeed, machines are increasingly mobilized to support the bureaucratic and technical management of flows, with a growing level of autonomy conferred to them by advances in artificial intelligence research. In that context, it is necessary to inquire into the role of algorithms in shaping and managing flows, and better conceptualize what these developments imply for the entanglements of humans and non-humans.

All these questions open new theoretical perspectives for criminologists, but will also spur methodological innovation. Being able to observe how flows move and are being controlled at multiple junctures of their stream will require ambitious research protocols that can capture a diversity of governance practices and rationalities being deployed at a global scale and over time. Understanding and explaining how their articulation forms a more or less coherent whole and how human-machine interactions influence their outcomes will require empirical creativity. What we hope to achieve with this special issue on Criminology in the Face of Flows is open the conversation for 
inventing new conceptual, theoretical and methodological tools to help criminology tackle and better understand the mobile, fluid and "liquid" world we're living in. 


\section{References}

Aas, K.F.,.2007. Analysing a world in motion. Global flows meet 'criminology of the other'. Theoretical Criminology, 11 (2), 283-303.

Aliverti, A., 2013. Crimes of Mobility. Criminal Law and the Regulation of Immigration. London: Routledge.

Amicelle, A., 2011. Towards a 'New' Political Economy of Financial Surveillance. Security Dialogue, 42 (4), 161 178.

Amicelle, A., Aradau C., and Jeandesboz, J., 2015. Questioning security devices: Performativity, resistance, politics. Security Dialogue, 46 (4), 293-306.

Amicelle, A., and Jacobsen K.U.E., 2016. The Cross-Colonization of Finance and Security through Lists: Banking Policing in the UK and India. Environment and Planning D: Society and Space, 34 (1), 89-106.

Balzacq, T., et al., 2010. Security Practices. In: RA Denemark, ed. International Studies Encyclopedia Online. Blackwell, 1-30.

Bauman, Z., 2000. Liquid Modernity. Cambridge: Polity Press.

Bauman, Z., et al., 2014. After Snowden: Rethinking the impact of surveillance. International Political Sociology, 8, 121-144.

Bayley, D., and Shearing, C., 1996. The future of policing. Law and Society Review, 30 (3), 585-606.

Beattie, J.M., 2002. Policing and Punishment in London 1660 - 1720: Urban Crime and the Limits of Terror. Oxford: Oxford University Press.

Beattie, J.M., 2012. The First English Detectives: The Bow Street Runners and the Policing of London, 1750-1840. Oxford: Oxford University Press.

Bigo, D., 2014. Security, IR and anthropology: Encounters, Misunderstanding and Possible Collaborations. In: M. Maguire, C. Fruits, and N. Zurawski, ed. The anthropology of security: perspectives from the frontline of policing, counter-terrorism and border control. London: Palgrave, 189-205.

Braithwaite, J., and Drahos, P., 2000. Global Business Regulation. Cambridge: Cambridge University Press.

Brodeur, J.-P., 2010. The Policing Web. Oxford: Oxford University Press.

Brown, W., 2010. Walled States, Waning Sovereignty. Cambridge MA: Zone Books.

Booth, K., 1991. Security and emancipation. Review of International Relations, 17 (4), 313-26.

Booth, K., 2007. Theory of world security. Cambridge: Cambridge University Press.

Bosworth, M., 2014. Inside Immigration Detention. Oxford: Oxford University Press.

Bowling, B., and Sheptycki, J., 2012. Global Policing. London: Sage. 
Boy, N., 2015. Report on the theory of risk as a societal security instrument [online]. Oslo: Source, Societal Security Network. Available from: http://www.societalsecurity.net/sites/default/files/D5.1\%20Report\%20on\%20the\%20theory\%20of\%20risk\%20 as\%20a\%20societal\%20security\%20instrument_version2.pdf [Accessed 9 June 2016].

Brewer, R., 2014. Policing the Waterfront. Networks, partnerships, and the governance of port security. Oxford: Oxford University Press.

Buzan, B., 1991. People, states \& fear: An agenda for international security studies in the post-Cold War era. London: Harvester Wheatsheaf.

Caldeira, T., 1996. Fortified Enclaves: The New Urban Segregation. Public Culture, 8 (2), 303-28.

Castells, M., 2000. The Rise of the Network Society. Oxford: Blackwell Publishers.

Côté-Boucher, K., 2016. The paradox of discretion: Customs and the changing occupational identity of Canadian border officers. British Journal of Criminology, 56 (1), 49-67.

De Goede, M., 2012. Speculative security: The politics of pursuing terrorist monies. Minneapolis: University of Minnesota Press.

Delumeau, J., 1989. Rassurer et protéger. Le sentiment de sécurité dans l'Occident d'autrefois. Paris: Fayard.

Dillon, M., 1996. Politics of security: towards a political philosophy of continental thought. London ; New York: Routledge.

Ericson, R.V., and Haggerty, K.D., 1997. Policing the Risk Society. Toronto: University of Toronto Press.

Foucault, M., 2009. Security, Territory, Population: Lectures at the Collège de France 1977-1978. London: Picador.

Garland, D., 1996. The Limits of the Sovereign State: Strategies of Crime Control and Contemporay Society. The British Journal of Criminology, 36 (4), 445-71.

Gros, F., 2012. Le Principe sécurité. Paris: Gallimard.

Hermitte, M.-A., 2003. La traçabilité des personnes et des choses. Précaution, pouvoirs et maitrise. In: P. Pedrot, ed. Traçabilité et responsabilité. Paris: Economica, 1-44.

Huysmans, J., 2014. Security Unbound: Enacting Democratic Limits. London: Routledge.

Kotef, H., 2015. Movement and the Ordering of Freedom. Durham: Duke University Press.

Langley, P., 2013. Toxic assets, turbulence and biopolitical security: Governing the crisis of global financial circulation. Security Dialogue, 44 (2), 111-126.

Latour, B., 2005. Reassembling the Social: An Introduction to Actor-Network-Theory. Oxford: Oxford University Press. 
Levi, M., and Reuter, P., 2006. Money Laundering. In: M. Tonry, ed. Crime and Justice: A review of Research. Chicago: Chicago University Press, 289-375.

Lobo-Guerrero, L., 2008. "Pirates", Stewards, and the Securitization of Global Circulation. International Political Sociology, 2 (3), 219-235.

Loftus. B.. 2015. Border regimes and the sociology of policing. Policing and Society: An International Journal of Research and Policy, 25 (1), 115-125.

Lyon, D., 2007. Surveillance Studies: an Overview. Cambridge: Polity Press.

McCulloch, J., and Pickering, S., 2012. Borders and Crime. Pre-crime, mobility and serious harm in an age of globalization. London: Palgrave Macmillan.

Morselli, C., 2010. Inside Criminal Networks. New York: Springer.

Nadelmann, E.A., 1993. Cops Across Borders. The internationalization of U.S. Criminal Enforcement. University Park: Penn State University Press.

Pallister-Wilkins, P., 2016. How Walls Do Work: Security Barriers as Devices of Interruption and Data Capture. Security Dialogue, 47, 151-164.

Parker, C., et al. 2004. Introduction in Regulation Law. In: C. Parker, et al., ed. Regulating Law. Oxford: Oxford University Press, 1-12.

O’Malley, P., 1996. Risk and Responsibility. In: Pp. N. Barry, A. Osbrone, and T. Rose, ed. Foucault and Political Reason: Liberalism, Neo-Liberalism and Rationalities of Government. Chicago: University of Chicago Press, 189208.

O'Reilly, C., 2010. The transnational security consultancy industry: a case of state-corporate symbiosis. Theoretical Criminology, 14 (2), 183-210.

O’Reilly, C., and Ellison, G., 2006. 'Eye spy private high': Re-conceptualizing high policing theory. British Journal of Criminology, 46 (4), 641-660.

Radzinowicz, L., 1948. A History of English Criminal Law and It's Administration from 1750: The Movement for Reform. Volume 1. London: Stevens \& Sons.

Rumsfeld, D., 2002. U.S. Department of Defense news briefing, February 12.

Schuilenburg, M., 2015. The Securitization of Society. New York: New York University Press.

Shearing, C., 1999. Remarks on Zero Tolerance. Criminal Law Bulletin, 35 (4), 378-83.

Shearing, C., and Wood, J., 2003. Nodal Governance, Democracy, and the New 'Denizens'. Journal of Law and Society, 30 (3), 400-419.

Stinchcombe, A., 1963. Institutions of Privacy in the Dermination of Police Administrative Practices. American Journal of Sociology, 69 (2), 150-160. 
Torny, D., 1998. La traçabilité comme technique de gouvernement des hommes et des choses. Politix, 11 (44), 51-75.

Valverde, M., 2010. Questions of security: A framework for research. Theoretical Criminology, 15, 3-22.

Zedner, L., 2003. The concept of security: an agenda for comparative analysis. Legal studies, 23, 153-176. 